\title{
Trophic position of Antarctic amphipods - enhanced analysis by a 2-dimensional biomarker assay
}

\author{
Fabienne Nyssen ${ }^{1,3, *}$, Thomas Brey ${ }^{4}$, Patrick Dauby ${ }^{2}$, Martin Graeve ${ }^{4}$ \\ ${ }^{1}$ Centre MARE, Laboratoire d'océanologie, and ${ }^{2}$ Systématique et Biodiversité animale, Université de Liège, \\ Institut de chimie, B6, Sart-Tilman, 4000 Liège, Belgium \\ ${ }^{3}$ Institut Royal des Sciences Naturelles de Belgique, Invertébrés récents, rue Vautier 29, 1000 Bruxelles, Belgium \\ ${ }^{4}$ Alfred Wegener Institute for Polar and Marine Research, Am Handelshafen 12, 27570 Bremerhaven, Germany
}

\begin{abstract}
The discrepancy between the ecological significance of amphipods in the Antarctic and our poor knowledge of their ecofunctional role calls for a more detailed investigation of their trophic status in this ecosystem. A total of 12 amphipod species from suspension feeder to scavenger have been considered in this study. Our objective was to investigate whether the combination of fatty-acid and stable-isotope signatures into a 2-dimensional trophic biomarker assay would increase accuracy in the identification of Antarctic benthic amphipod trophic position. Amphipod isotopic averages ranged from $-29.3 \%\left(\delta^{13} \mathrm{C}\right)$ and $4.1 \%\left(\delta^{15} \mathrm{~N}\right)$ for the suspension feeder Ampelisca richardsoni to $-21.7 \%$ o $\left(\delta^{13} \mathrm{C}\right)$ and $11.9 \%$ o $\left(\delta^{15} \mathrm{~N}\right)$ for the high predator Iphimediella sp. Cluster analysis of the fattyacid composition separated the amphipod species into 4 trophic groups: suspension feeders, macroherbivores, omnivores and scavengers. The suspension feeder was isolated due to an important proportion of 18:4(n-3), a fatty-acid biomarker of phytoplankton. Macro-herbivores were found to rely heavily on macroalgal carbon, containing a high percentage of arachidonic acid (20:4(n-6)). Scavenger amphipods revealed a unique fatty-acid composition dominated by 1 single fatty acid, 18:1(n9), probably the result of a very intensive de novo biosynthesis to cope with starvation periods. Our data emphasise the need to combine different types of information to be able to draw the right conclusions regarding trophic ecology. Indeed, in some cases, the exclusive use of 1 type of tracing method, fatty acids or stable isotopes, would have resulted in misleading/false conclusions in the trophic classification of amphipods. Therefore, a 2-dimensional biomarker assay is a useful tool to elucidate the trophic positions of benthic amphipods.
\end{abstract}

KEY WORDS: 2-dimensional biomarker - Trophic relationships - Stable isotopes - Fatty acids · Amphipoda $\cdot$ Antarctic ecology

\section{INTRODUCTION}

In the Southern Ocean, amphipod crustaceans are among the most specious animal groups in the zoobenthos. About 530 species have been recorded as strictly Antarctic species, and $>830$ species have been described so far for the whole Southern Ocean (Klages 1991, De Broyer \& Jazdzewski 1996, De Broyer et al. 1999, 2003a,b, Gutt et al. 2000). It is commonly assumed that species and trophic diversity are related (Ulanowicz 2000, Dauby et al. 2001b). Also, in Antarctic waters and on Antarctic bottoms, amphipods have developed a rich variety of life styles: epontic dwellers, (bentho-)pelagic swimmers, walkers, crawlers and burrowers. They occupy many niches reserved for decapod crustaceans in other systems (Dauby et al. 2001a,b, De Broyer et al. 2001). This diversity in life style, associated with the variety of available food, is likely to be a factor that has favoured the adaptative radiation of the Amphipoda and the diversification of trophic types in Antarctic waters (Jazdzewski et al. 1996, Dauby et al. 2001b, De Broyer et al. 2001). Regarding total energy flow in the eastern Weddell Sea shelf ecosystem, amphipods are among the key taxa in the benthic sub-system (Jarre-Teichmann et al. 1997, Dauby et al. 2003). 
Biomarkers such as fatty acids and stable isotopes have been used successfully to identify trophic relationships in marine food webs (Hobson et al. 1995, Lepoint et al. 2000, Graeve et al. 2001, Auel et al. 2002, Nyssen et al. 2002). Fatty acids are the primary constituents of most lipids. They generally remain intact through digestion and can be deposited in the consumer's tissue with minimal modification from diet and in a predictable way (Lee et al. 1971). Certain fatty acids have specific known sources and can act as biomarkers. These features make fatty acids a potential food-chain tracer in marine ecosystems, which has shown its suitability in various studies (Sargent 1976, Sargent \& Henderson 1986, Graeve et al. 2001, Iverson et al. 2002, Dalsgaard et al. 2003).

Stable isotope ratios also provide signatures based on actual food assimilation, but are integrated over a period corresponding to the turnover time of the analysed tissues (Tieszen et al. 1983, Hobson et al. 1996, 1997). The technique relies upon the direct relationship between the carbon $\left(\delta^{13} C\right)$ and nitrogen $\left(\delta^{15} N\right)$ stable isotope ratios of animals and those of their diets (De Niro \& Epstein 1978, 1981, Peterson \& Fry 1987). Changes in ratios (i.e. fractionation) occur through metabolic processes, which cause change in the relative proportions of stable isotopes. As a result, the stable isotope composition of a consumer is indicative of and in general heavier than that of its prey. The more conservative transfer of carbon isotopic compositions ( 0.5 to $1 \%$ enrichment per trophic transfer) can be useful to trace 2 food sources with clear differences in their $\delta^{13} \mathrm{C}$ values, whereas nitrogen ratios (3 to $4 \%$ enrichment per trophic transfer) are most frequently used as trophic position indicators (Minagawa \& Wada 1984, Hobson \& Welch 1992, Michener \& Schell 1994, Lepoint et al. 2000). However, it must be considered that fractionation is not constant and that many factors can cause variation (Gannes et al. 1997), e.g. species (e.g. De Niro \& Epstein 1981), food source (Fantle et al. 1999), nitrogen dietary content (Adams \& Sterner 2000), or nutritional or hydric stress (Hobson et al. 1993). Despite those problems, isotopes have been successfully applied to the Antarctic trophic web (Wada et al. 1987, Burns et al. 1998) and particularly to the pelagic fauna and the top predators of the Weddell Sea (Rau et al. 1991a,b, 1992, Schmidt et al. 2003). Only a few stable-isotopic studies have been focussed on benthic communities so far (Dunton 2001, Nyssen et al. 2002). Likewise, there are limited lipid studies of Antarctic benthic amphipods (Nelson et al. 2001, Graeve et al. 2001). More work has been conducted in the Arctic (Hobson et al. 1995, Auel et al. 2002) and on Antarctic pelagic amphipods, e.g. Themisto gaudichaudii (Reinhardt \& Van Vleet 1986, Hagen 1988, Phleger et al. 1998).
The discrepancy between the ecological significance of amphipods and our poor knowledge of their ecofunctional role calls for a more detailed investigation of their share in Antarctic trophodynamics. Furthermore, the profusion of amphipod species and the variability of their trophic spectrum in the Southern Ocean mandates a more systematic and efficient approach towards this aspect of their ecology. Our study investigates whether the combination of fatty-acid and stable-isotope signatures into a 2-dimensional trophic biomarker will increase accuracy in the identification of Antarctic benthic amphipod trophic position.

\section{MATERIALS AND METHODS}

Sampling and storage. The amphipods Waldeckia obesa (Chevreux, 1905), Abyssorchomene plebs (Hurley, 1965), Eurythenes gryllus (Lichtenstein, 1822), Pseudorchomene coatsi (Chilton, 1912), Epimeria similis (Chevreux, 1912), Epimeria georgiana (Schellenberg, 1931), Iphimediella sp., Echiniphimedia hodgsoni (Walker, 1906), Eusirus perdentatus (Chevreux, 1912), Djerboa furcipes (Chevreux, 1906) and Ampelisca richardsoni (Karaman, 1975) were caught during the cruises ANT XIX/3\&4 (ANDEEP I\&II), 23 January to 1 April 2002 (De Broyer et al. 2003a), with RV 'Polarstern', to the Antarctic Peninsula (Fig. 1). The animals were taken from various depths by different gear: Agassiz trawls, bottom trawls and autonomous traps. Immediately after sampling, individuals were sorted into species and kept for several hours in aquaria. Thereafter, individuals dedicated to isotope analyses were rinsed in distilled water and transferred into glass vials. Specimens for lipid analysis were transferred into glass vials and covered with dichloromethan:methanol (2:1 by volume). All samples were stored at $-30^{\circ} \mathrm{C}$ until analysis at the Alfred Wegener Institute in Bremerhaven.

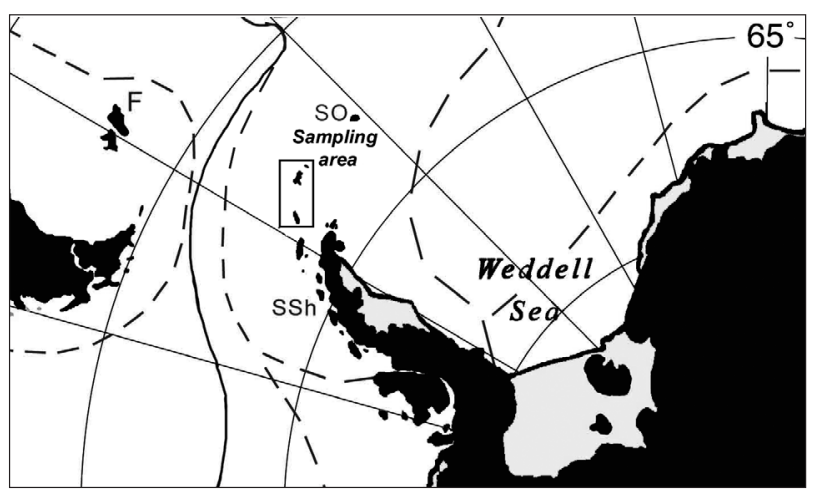

Fig. 1. Antarctic Peninsula and sampling areas (F: Falklands; SO: South Orkneys; SSh: South Shetlands) 
Stomach content analysis. Gut contents of 20 specimens from each species preserved in $4 \%$ formaldehyde solution were examined. The digestive tract was removed from the animal, opened and the content was spread on a microslide. The slide was examined microscopically (Leica DMLB with reflection contrast system), and every food item was determined as precisely as possible. Additional data were taken from Nyssen et al. (2002) and Dauby et al. (2001b), where the methodological details are described. Observations of feeding behaviour of the various amphipod species in aquaria provided further information on diet and feeding.

Lipid analysis. Lipid analyses were carried out on all sampled amphipod species $(\mathrm{n}=11)$. Fatty acid data from Graeve et al. (2001) referring to the species Ampelisca richardsoni, Echiniphimedia hodgsoni, Oradarea edentata, Epimeria georgiana (1 specimen) and Eusirus perdentatus were added to our data set for comparison.

Samples stored in chloroform:methanol (2:1 by volume) were evaporated with nitrogen to dryness and subsequently lyophilised for $48 \mathrm{~h}$. Dry mass (DM) was determined gravimetrically. Total lipid mass (TL) was measured gravimetrically after lipid extraction from the freeze-dried samples using dichloromethane: methanol (2:1 by volume), essentially after Folch et al. (1957).

Fatty-acid composition was analysed by gas-liquid chromatography (Kattner \& Fricke 1986). Fatty acids of the total lipid extracts were converted to their methyl esters by transesterification in methanol containing $3 \%$ concentrated sulphuric acid at $80^{\circ} \mathrm{C}$ for $4 \mathrm{~h}$. After extraction with hexane, fatty acid methyl esters were analysed with a Hewlett-Packard 6890 series gas chromatograph, with a DB-FFAP fused silica capillary column $(30 \mathrm{~m} \times 0.25 \mathrm{~mm}$ inner diameter; $0.25 \mu \mathrm{m}$ film thickness) using temperature programming (160 to $240^{\circ} \mathrm{C}$ at $4^{\circ} \mathrm{C} \mathrm{min}^{-1}$, hold $15 \mathrm{~min}$ ). For recording and integration Class-VP software (4.3) (Shimadzu) was used. Fatty acids were identified with commercial and natural standard mixtures and, if necessary, additional confirmation was carried out by gas chromatography-mass spectrometry.

Stable-isotope analysis. Carbon and nitrogen isotopic ratios were measured in all sampled amphipod species ( $n=11$, no isotopic data available for Oradarea edentata), as well as in the brown alga Desmarestia mensiezii. Isotopic data for suspended particulate organic matter (SPOM) are from Nyssen et al. (2002). Muscle tissues or whole animals of small species were dried and ground with mortar and pestle into a homogenous powder. Isotopic ratios were measured individually in each specimen. Stable carbon and nitrogen isotope ratios were analysed with a nitrogen-carbon elemental analyser (Fisons) directly coupled to an Optima (Micromass) continuous flow isotope ratio mass spectrometer (CF-IRMS) for combustion and automated analysis. Isotopic ratios are expressed in $\delta$-values as the proportional deviation of the sample isotope ratio from that of an international Vienna Peedee Belemnite (V-PDB) standard according to the following formula:

$$
\delta X(\%)=\left[R_{\text {sample }}-R_{\text {standard }} / R_{\text {standard }}\right] \times 1000
$$

where $X$ is ${ }^{13} \mathrm{C}$ or ${ }^{15} \mathrm{~N}, R$ is ${ }^{13} \mathrm{C} /{ }^{12} \mathrm{C}$ or ${ }^{15} \mathrm{~N} /{ }^{14} \mathrm{~N}$, and the appropriate standards were $\mathrm{V}-\mathrm{PDB}$ and atmospheric nitrogen for carbon and nitrogen, respectively. Intercomparison materials were IAEA-N1 $\left(\delta^{15} \mathrm{~N}=+0.4 \pm\right.$ $0.2 \%$ ) and IAEA CH-6 (sucrose) $\left(\delta^{13} \mathrm{C}=10.4 \pm 0.2 \%\right.$ ). Experimental precision (based on the standard deviation of replicates of an atropina standard) was $0.3 \%$ for both carbon and nitrogen.

Data analysis. Multivariate analyses of the fatty-acid composition were performed for all individuals using the program PRIMER (Plymouth Routines in Multivariate Ecological Research), Version 5 (Clarke \& Warwick 1994). Hierarchical clustering and multi-dimensional scaling (MDS) were performed based on a Bray-Curtis similarity coefficient applied to untransformed percentage composition data. No transformation was applied to the data set, because those fatty acids that contribute only to a small percentage of the total composition did not feature heavily in the diet. Giving artificial weight to these minor fatty acids by applying a transformation would therefore be inappropriate. Data from Graeve et al. (2001) referring to the species Ampelisca richardsoni, Echiniphimedia hodgsoni, Oradarea edentata, Epimeria georgiana (1 specimen) and Eusirus perdentatus were added to our data set for comparative analysis.

The SIMPER (SIMilarity PERcentage - species contribution) routine in PRIMER was used to investigate the clusters found by both hierarchical cluster analysis and MDS.

Parametric tests were used to compare isotope ratios between different taxa. Normality of the data was checked by the Kolmogorov-Smirnov test, followed by ANOVA and post hoc (Tukey test) comparisons of means. A significance level of $p<0.001$ was used in all tests (Scherrer 1984) except when it is mentioned.

\section{RESULTS}

\section{Stomach content and trophic type}

Major stomach contents and corresponding trophic type of the 11 amphipod species are summarised in Table 1. Detailed stomach content data are provided by Dauby et al. (2001b) and Nyssen et al. (2002). Trophic type of the 11 species ranged from suspension feeder to scavenger. 
Table 1. Classification of 11 species of Antarctic amphipods in different trophic categories following the composition of their stomach content (Dauby et al. 2001b, Nyssen et al. 2002, present study)

\begin{tabular}{|lll|}
\hline Species & Trophic type & Major prey \\
\hline Ampelisca richardsoni & Suspension feeder & Phytoplankton \\
Djerboa furcipes & Herbivore & Brown macroalgae \\
Epimeria similis & Micropredator & Hydrozoans \\
Epimeria georgiana & Deposit feeder & Detritus \\
Eusirus perdentatus & Predator & Crustaceans \\
Echiniphimedia hodgsoni & Micropredator & Sponges \\
Iphimediella sp. & Predator & Crustaceans \\
Pseudorchomene coatsi & Scavenger & Carrion \\
Abyssorchomene plebs & Scavenger & Carrion \\
Eurythenes gryllus & Scavenger & Carrion \\
Waldeckia obesa & Scavenger & Carrion \\
\hline
\end{tabular}

\section{Fatty-acid composition}

The fatty-acid composition, albeit different between species, showed some overall similarities (Table 2). The principal fatty acids of all species were 16:0, 18:1 (both isomers), 20:4(n-6), 20:5(n-3) and 22:6(n-3). High percentages of polyunsaturated fatty acids (PUFA) were found in Ampelisca richardsoni (58\%), whereas monounsaturated fatty acids (MUFA) were most abundant in Eurythenes gryllus, accounting for up to $58 \%$. The hierarchical cluster analysis separated 12 amphipod species into 5 distinct groups at the $80 \%$ similarity level (Fig. 2). Clusters 1 and 5 (C1 and C5) are mono-specific, and $\mathrm{C} 4$ is well separated into single species groupings. In $\mathrm{C} 2$ and $\mathrm{C} 3$, the individuals are not gathered by species in subgroups, but more spread, although some separation was still apparent. Iphimediella sp. and 1 specimen of Echiniphimedia hodgsoni remained outside the clusters defined at the $80 \%$ similarity level. As shown by SIMPER analysis (Table 3), these groupings had high within-group similarities. The statistical treatment, using all fatty acids for each group, indicated that essentially oleic acid (18:1(n-9)) distinguished C1 (Waldeckia obesa) from all other clusters. The fatty-acid profile of $W$. obesa was unique, since oleic acid accounted for $>44 \%$ of total fatty acids. This unusually high proportion of oleic acid is responsible for the split of scavenger species into 2 different clusters (C1 \& C2). The SIMPER analysis revealed also that it is mainly the higher proportion of the fatty acid 18-4(n-3) which isolates C5 from the other clusters. The highest levels of $\mathrm{C}_{18}$ and $\mathrm{C}_{20}$ PUFA (mainly arachidonic acid, 20:4(n-6), which is the discriminant fatty acid for this cluster) occurred in C4 (Djerboa furcipes and

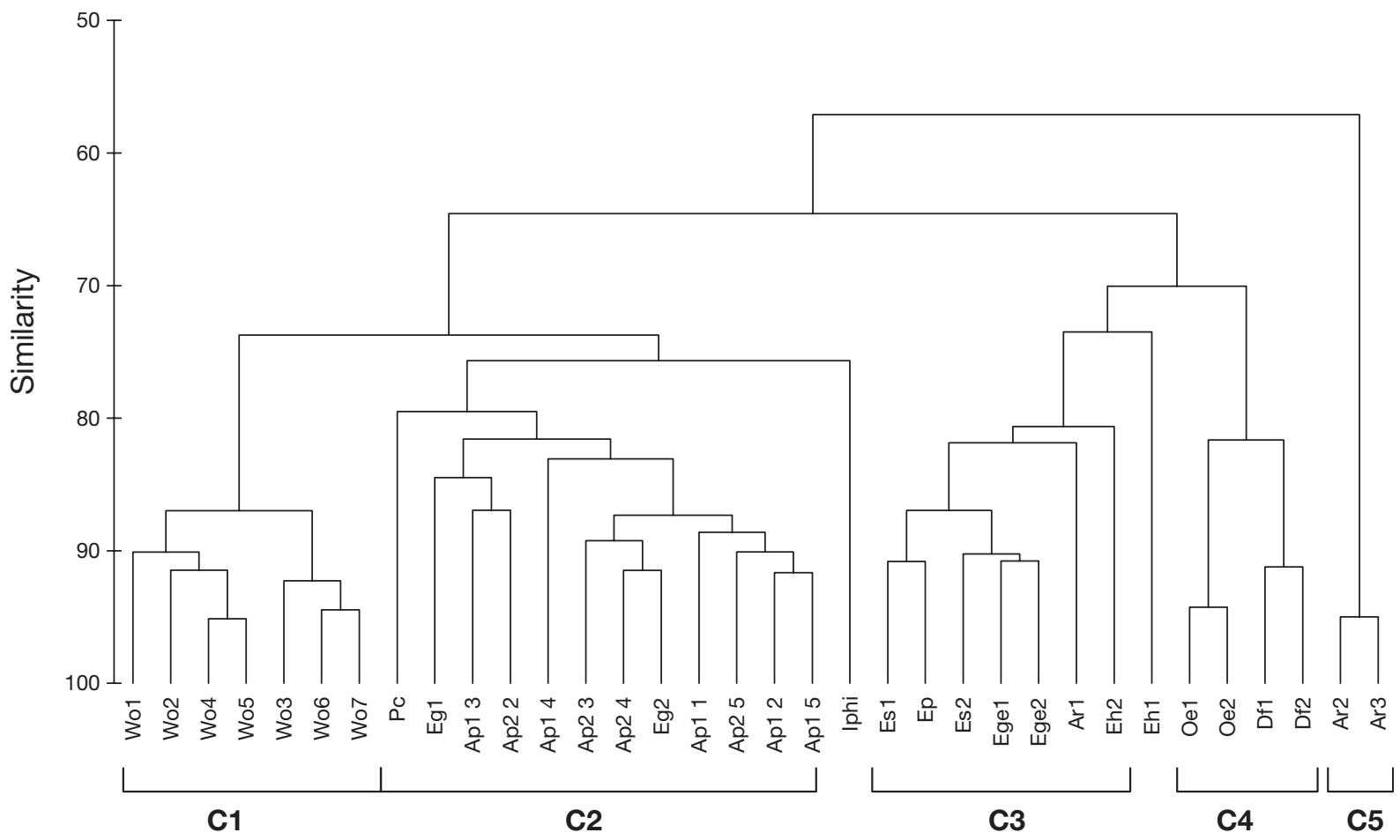

Fig. 2. Hierarchical cluster analysis of fatty-acid composition (\%) of the total lipid extracted from 12 species of Antarctic amphipods. Species abbreviations as in Table 2 


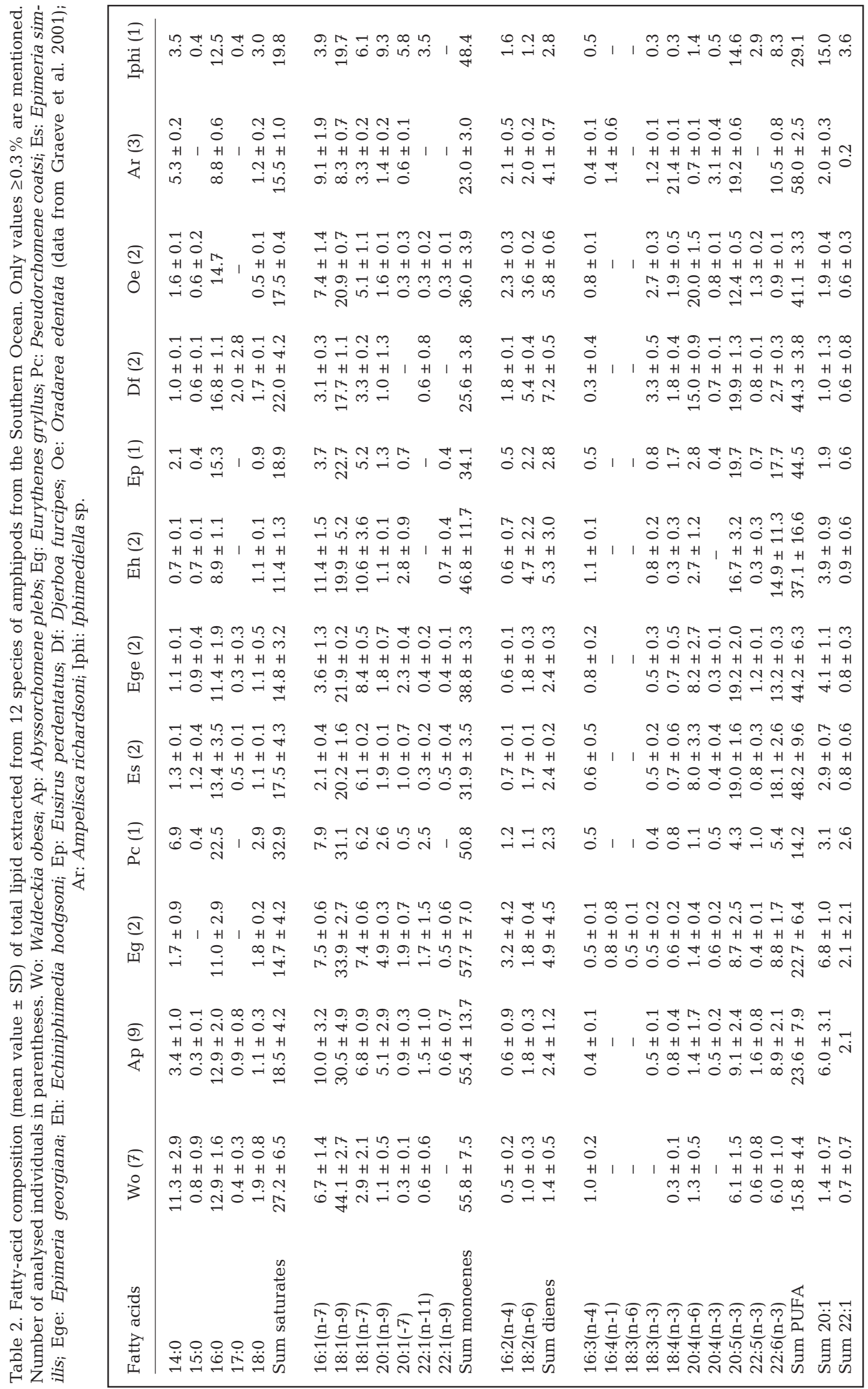


Oradarea edentata). Besides all the clusters, the isolated position of the iphimediid species in the dendrogram seems to be due to its considerably high levels of 20:1 and 22:1 fatty acids (19\% in total).

\section{Stable-isotope ratios}

The average carbon and nitrogen isotope ratios range from $-29.3 \%\left(\delta^{13} \mathrm{C}\right)$ and $4.1 \%\left(\delta^{15} \mathrm{~N}\right)$ in Ampelisca richardsoni to $-21.7 \%$ o $\left(\delta^{13} \mathrm{C}\right)$ and $11.9 \%\left(\delta^{15} \mathrm{~N}\right)$ in Iphimediella sp. The inter-species differences are significant, as indicated by ANOVA and subsequent post hoc tests (Table 4). Displaying the lowest isotopic ratios, A. richardsoni $\left(\delta^{13} \mathrm{C}=-29.3 \pm 0.2 \% ; \delta^{15} \mathrm{~N}=4.1 \pm 0.1 \%\right.$ o $)$ and Djerboa furcipes $\left(\delta^{13} \mathrm{C}=-27.8 \pm 0.6 \% ; \delta^{15} \mathrm{~N}=4.9 \pm 0.3 \%\right)$ resemble primary producers, i.e. the SPOM and the brown macroalga Desmarestia mensiezii. The isotopic ratios of these primary consumers are significantly different from values of all the other species (Tukey test, $\mathrm{p}<0.001$ ).

Both Epimeriidae and the species Eusirus perdentatus show wide ranges of isotopic ratios. As illustrated in

Table 3. Results of SIMPER analysis: within-group similarity (\% in parentheses under cluster), average dissimilarity (\%) and separating fatty acids (FA) (most discriminant)

\begin{tabular}{|c|c|c|c|c|c|}
\hline & $\begin{array}{c}\text { CLUSTER } 1 \\
(89.1 \%)\end{array}$ & $\begin{array}{c}\text { CLUSTER } 2 \\
(83.7 \%)\end{array}$ & $\begin{array}{c}\text { CLUSTER } 3 \\
(81.8 \%)\end{array}$ & $\begin{array}{c}\text { CLUSTER } 4 \\
(85.3 \%)\end{array}$ & $\begin{array}{c}\text { CLUSTER } 5 \\
(95.0 \%)\end{array}$ \\
\hline CLUSTER 1 & - & $\begin{array}{c}25.4 \\
18: 1(n-9) / 14: 0\end{array}$ & $\begin{array}{c}41.1 \\
18: 1(n-9) / 20: 5(n-3)\end{array}$ & $\begin{array}{c}44.3 \\
18: 1(n-9) / 20: 4(n-6)\end{array}$ & $\begin{array}{c}50.5 \\
18: 1(n-9) / 18: 4(n-3)\end{array}$ \\
\hline CLUSTER 2 & & - & $\begin{array}{c}29.7 \\
18: 1(\mathrm{n}-9) / 20: 5(\mathrm{n}-3)\end{array}$ & $\begin{array}{c}36.8 \\
20: 4(n-6) / 18: 1(n-9)\end{array}$ & $\begin{array}{c}43.2 \\
18: 1(n-9) / 18: 4(n-3)\end{array}$ \\
\hline CLUSTER 3 & & & - & $\begin{array}{c}29.9 \\
22: 6(n-3) / 20: 4(n-6)\end{array}$ & $\begin{array}{c}36.7 \\
18: 4(n-3) / 18: 1(n-9)\end{array}$ \\
\hline CLUSTER 4 & & & & - & $\begin{array}{c}44.5 \\
18: 4(n-3) / 20: 4(n-6)\end{array}$ \\
\hline CLUSTER 5 & & & & & - \\
\hline
\end{tabular}

Table 4. ANOVA results: post hoc test (Tukey test) for (a) $\delta^{13} \mathrm{C}$ and (b) $\delta^{15} \mathrm{~N}^{*}$ : : significant with $\mathrm{p}<0.001^{i^{* *}}{ }^{*}$ : significant with $\mathrm{p}<0.005$; ns: no significant difference between means at $\alpha=0.05$; n: number of samples

\begin{tabular}{|c|c|c|c|c|c|c|c|c|c|c|c|c|c|c|}
\hline & Species & $\mathrm{n}$ & & 1 & 2 & 3 & 4 & 5 & 6 & 7 & 8 & 9 & 10 & 11 \\
\hline \multicolumn{15}{|c|}{ (a) $\delta^{13} \mathrm{C}$} \\
\hline 1 & Ampelisca richardsoni & 3 & $-29.3 \pm 0.2$ & & ns & * & $*$ & $*$ & * & * & ${ }^{* *}$ & ns & $*$ & * \\
\hline 2 & Djerboa furcipes & 5 & $-27.8 \pm 0.6$ & & & * & * & * & $* *$ & * & ns & ns & $*$ & * \\
\hline 3 & Epimeria similis & 15 & $-25.0 \pm 1.5$ & & & & $*$ & $* *$ & ns & $*$ & ns & * & ns & ${ }^{* *}$ \\
\hline 4 & Epimeria georgiana & 17 & $-23.7 \pm 1.7$ & & & & & ns & ns & $\mathrm{ns}$ & ${ }^{*}$ & ${ }^{*}$ & ns & ns \\
\hline 5 & Eusirus perdentatus & 14 & $-23.4 \pm 0.6$ & & & & & & ns & $\mathrm{ns}$ & ${ }^{*}$ & * & ns & ${ }^{* *}$ \\
\hline 6 & Echiniphimedia hodgsoni & 2 & $-24.3 \pm 1.3$ & & & & & & & $\mathrm{~ns}$ & $\mathrm{~ns}$ & ${ }^{* *}$ & $\mathrm{~ns}$ & ns \\
\hline 7 & Iphimediella sp. & 4 & $-21.7 \pm 1.2$ & & & & & & & & $*$ & $*$ & ns & ns \\
\hline 8 & Abyssorchomene plebs & 6 & $-26.6 \pm 0.5$ & & & & & & & & & ns & ${ }^{*}$ & ${ }^{*}$ \\
\hline 9 & Eurythenes gryllus & 9 & $-27.3 \pm 1.1$ & & & & & & & & & & $*$ & * \\
\hline 10 & Pseudorchomene coatsi & 3 & $-22.7 \pm 0.3$ & & & & & & & & & & & ns \\
\hline 11 & Waldeckia obesa & 5 & $-22.8 \pm 0.9$ & & & & & & & & & & & \\
\hline \multicolumn{15}{|c|}{ (b) $\delta^{15} \mathrm{~N}$} \\
\hline 1 & Ampelisca richardsoni & 3 & $4.1 \pm 0.1$ & & ns & * & $*$ & $*$ & * & * & $*$ & $*$ & $*$ & * \\
\hline 2 & Djerboa furcipes & 5 & $4.9 \pm 0.3$ & & & * & $*$ & * & $*$ & * & $*$ & $*$ & $*$ & * \\
\hline 3 & Epimeria similis & 15 & $7.6 \pm 0.5$ & & & & ns & ns & $*$ & * & $*$ & ns & ns & ns \\
\hline 4 & Epimeria georgiana & 17 & $7.9 \pm 0.4$ & & & & & * & ns & * & ns & ns & ns & ns \\
\hline 5 & Eusirus perdentatus & 14 & $7.3 \pm 1.0$ & & & & & & * & * & ${ }^{*}$ & ns & ${ }^{*}$ & ns \\
\hline 6 & Echiniphimedia hodgsoni & 2 & $10.6 \pm 1.8$ & & & & & & & ns & ns & ns & ns & $*$ \\
\hline 7 & Iphimediella sp. & 4 & $11.9 \pm 0.9$ & & & & & & & & ${ }^{*}$ & * & ${ }^{* *}$ & ${ }^{*}$ \\
\hline 8 & Abyssorchomene plebs & 6 & $9.5 \pm 0.8$ & & & & & & & & & ns & ns & ** \\
\hline 9 & Eurythenes gryllus & 9 & $8.5 \pm 0.5$ & & & & & & & & & & ns & ns \\
\hline 10 & Pseudorchomene coatsi & 3 & $9.3 \pm 0.3$ & & & & & & & & & & & ns \\
\hline 11 & Waldeckia obesa & 5 & $7.3 \pm 0.7$ & & & & & & & & & & & \\
\hline
\end{tabular}


Fig. 3, the range of values is wider for $\delta^{13} \mathrm{C}$ than for the $\delta^{15} \mathrm{~N}$. The difference between maximum and minimum $\delta^{13} \mathrm{C}$ is from 2.5 to $5.5 \%$. This difference is less pronounced for nitrogen (from 1.5 to $3 \%$ ). The species displaying the widest range of values is Epimeria georgiana. The scavengers are clearly separated into 2 groups, and this scission is essentially due to their significantly different $\delta^{13} \mathrm{C}$ (Tukey test, $\mathrm{p}<0.001$ ). The first group is composed of the lipid-rich species Abyssorchomene plebs and Eurythenes gryllus, while the second gathers the lipid-less Waldeckia obesa and Pseudorchomene coatsi (F. Nyssen \& M. Graeve unpubl. results).

The highest positioned species in the food web, Iphimediella sp., displays a significantly different $\delta^{15} \mathrm{~N}$ value to those of the other species (Tukey test, p < 0.001), except compared to Echiniphimedia hodgsoni, which belongs to the same family. However, the $\delta^{13} \mathrm{C}$ value shows some similarity with other species, such as Waldeckia obesa, Eusirus perdentatus, Pseudorchomene coatsi and Epimeria georgiana.

\section{The 2-dimensional biomarker approach}

In order to check whether the combination of fattyacid and stable-isotope data is useful to enhance the identification of trophic positions, $\delta^{15} \mathrm{~N}$ values were plotted versus 4 fatty-acid types that are characteristic biomarkers for certain food types or feeding strategies (Fig. 4).

The 18:1(n-9) fatty acid is considered to be a signature of carnivory (Graeve et al. 2001, Auel et al. 2002). There is a general positive relationship between $\delta^{15} \mathrm{~N}$ and 18:1(n-9) (Fig. 4A). The negative relationship between $\delta^{15} \mathrm{~N}$ and the polyunsaturated fatty acid 18:4(n-3), recognised as a biomarker of haptophytes (Graeve et al. 1994a,b), is illustrated in Fig. 4B. The distinction between primary consumers' food preferences is evident from a comparison of Fig. 4B,C. Finally, the plot of 20:1 and 22:1 fatty acids, synthesised only by calanoid copepods (Hagen et al. 1993, 2000, Graeve et al. 1994a,b, Kattner et al. 1994), against $\delta^{15} \mathrm{~N}$ shows a clear positive correlation (Fig. 4D).

\section{DISCUSSION}

SIMPER analysis, involving all fatty acids, revealed essentially the oleic acid as distinguishing $\mathrm{C} 1$ from all other clusters. The fatty-acid signature of Waldeckia obesa is characterised by extremely high levels of 18:1(n-9) and high levels of 14:0, compared to all other species. This unusual amount of 18:1(n-9) has already been recorded by Graeve et al. (2001) for the same species. Oleic acid is a major end product of the fatty-acid biosynthesis in vertebrates and invertebrates. For example, Iverson et al. (2002) have reported concentrations of $>30 \%$ of this fatty acid in Alaskan eulachon Thaleichthys pacificus. In Antarctic waters, the notothenioid fishes, such as the icedevil Aethotaxis mitopteryx and the silverfish Pleurogramma antarcticum, also display rather high levels of 18:1(n-9) fatty acid (about $25 \%$ of the total fatty acid composition) (Hagen et al. 2000), but none of them have ever been found to contain concentrations as high as those recorded in scavenging amphipods. The fatty acid 18:1(n-9), typically occurring in metazoans, is generally considered as a signature of carnivorous feeding (Sargent \& Henderson 1986, Falk-Petersen et al. 1990, Graeve et al. 1994b, 1997, Hagen \& Kattner 1998, Auel et al. 2002). Plotted against $\delta^{15} \mathrm{~N}$, which is a trophic indicator, a general positive correlation is observed, and an accumulation of 18:1(n-9) from the diet could be suggested. However, a particularly high de novo biosynthesis of 18:1(n-9) could also explain those high concentrations in Lysianassidae in general and in W. obesa in particular. These fatty acids could have been synthesised by amphipods in response to short periods of satiety followed by long periods of starvation, a common situation for scavengers. $\mathrm{C} 2$, comprising the other scav-

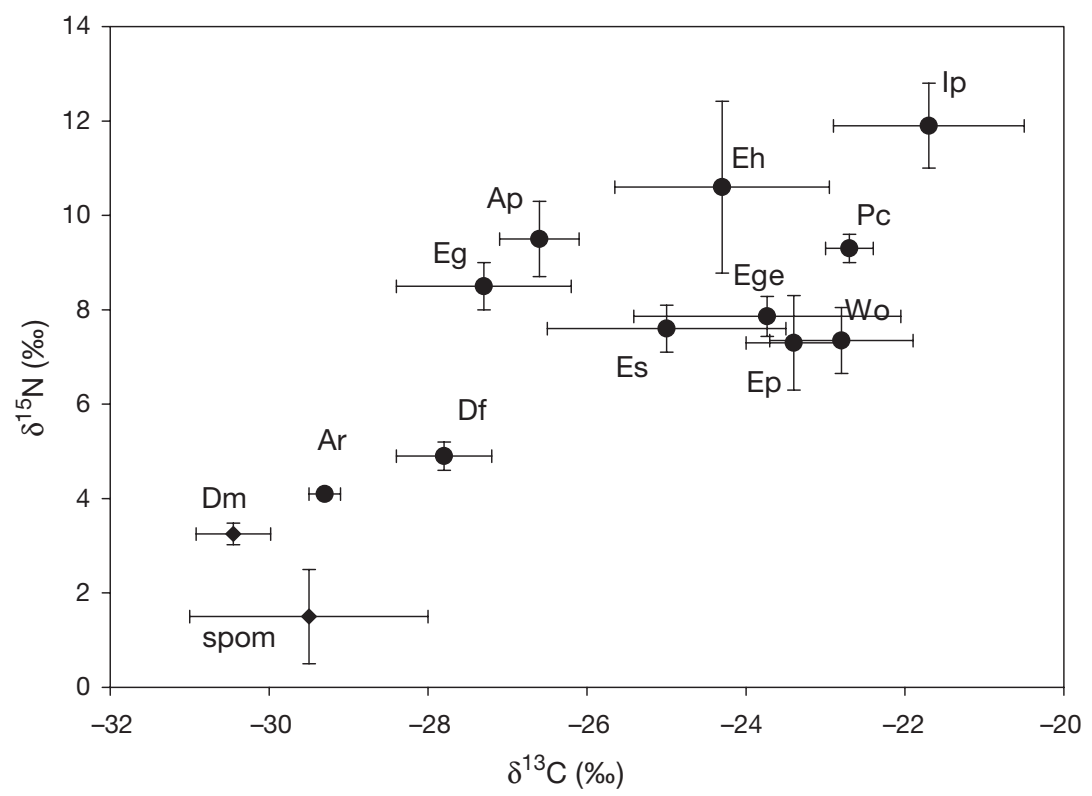

Fig. 3. Carbon and nitrogen isotopic ratios of 11 species of Antarctic amphipods. Ip: Iphimediella sp.; SPOM: suspended particulate organic matter (data from Nyssen et al. 2002); Dm: brown macroalgae Desmarestia mensiezii. Other species abbreviations as in Table 2 


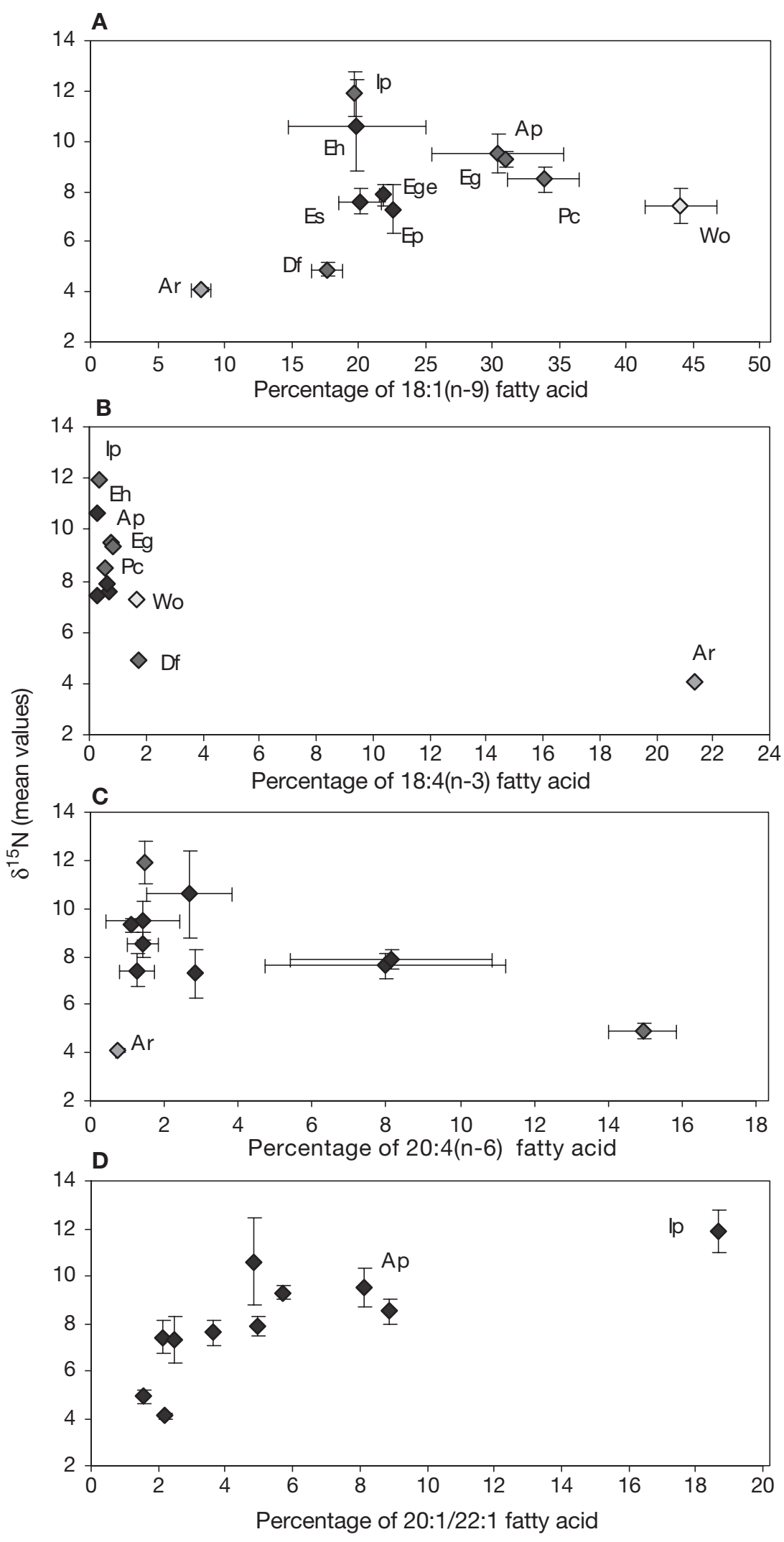

Fig. 4. Nitrogen-isotopic ratios plotted versus concentration of different fattyacid biomarkers (\% of total fatty acids) of 11 species of Antarctic amphipods. For species abbreviations see Table 2 and Fig. 3 engers Abyssorchomene plebs, Eurythenes gryllus and Pseudorchomene coatsi, is also characterised by high levels of 18:1(n-9), but to a lesser extent compared to $W$. obesa. This difference, associated with the different levels of 14:0 fatty acid, is responsible for $40 \%$ of the separation of scavenger amphipods in 2 different clusters.

Considering the isotopic results, the species Abyssorchomene plebs and Eurythenes gryllus are characterised by particularly low $\delta^{13} \mathrm{C}$ values compared to the other scavengers, Waldeckia obesa and Pseudorchomene coatsi. This depletion in carbon is probably due to the higher lipid content of A. plebs and E. gryllus (F. Nyssen \& M. Graeve unpubl. results). Lipids are isotopically lighter than proteins, and so high lipid content generally results in a decrease of the $\delta^{13} \mathrm{C}$ of the whole body (DeNiro \& Epstein 1977, Tieszen et al. 1983, Wada et al. 1987, Pinnegar \& Polunin 1999, Nyssen et al. 2002).

All these scavenging amphipods belong to the family Lysianassidae, and the conservation of a similar fatty-acid composition in all of these congeners is particularly striking. A potential link between phylogeny and fatty-acid composition in lysianassids would be an interesting topic in itself. Indeed, the fatty-acid composition of another Antarctic scavenger, the isopod Natatolana sp., is distinctly different, despite its almost identical feeding strategy and prey spectrum (F. Nyssen unpubl. data).

The high levels of $\mathrm{C}_{18}$ and $\mathrm{C}_{20}$ PUFAs (mainly arachidonic acid 20:4(n-6)) recorded in Djerboa furcipes and Oradarea edentata (C4) are in close accordance with their herbivorous diet. High concentrations of $\mathrm{C}_{18}$ and $\mathrm{C}_{20}$ polyunsaturated fatty acids have been shown to be typical of many macroalgae (Kayama et al. 1989, Cook et al. 2000, Graeve et al. 2001, Kharlamenko et al. 2001). Furthermore, judging by stomach-content results, the brown alga Desmarestia menziesii seems to be preferentially consumed by these herbivorous amphipods. The results are corroborated by the fatty-acid composition of the macroalgae, which are dominated by 
20:4(n-6), 18:1(n-9) and $C_{18}$ PUFAs (F. Nyssen unpubl. results). When plotted against the $\delta^{15} \mathrm{~N}$ of all species, the percentage of 20:4(n-6) displays a negative correlation: its concentration increases with the decreasing rank of the various species in the food web (Fig. 4C). Although they are not macroherbivore, both Epimeriidae species accumulate significant quantities of 20:4(n-6), up to $8 \%$. Although Graeve et al. (2002) suggested arachidonic acid as indicating macroalgal origin; other authors have suspected protists in the sediment to be one of the sources of 20:4(n-6) (Bell \& Sargent 1985, Fullarton et al. 1995, Howell et al. 2003). The presence of sediment in the stomach of Epimeria similis and E. georgiana has already suggested at least partial deposit-feeding behaviour, and 20:4(n-6) levels could reflect some assimilation of the sediment-associated micro-organisms. Furthermore, even with a significant amount of arachidonic acid, the intermediate nitrogen ratios of both Epimeriidae provide additional evidence of the distance to this source of the fatty-acid signature. These species probably do not belong to a well-defined trophic category, but are able to modulate their feeding behaviour in response to food availability. The combination of different approaches used here would help to avoid the classification of these epimeriid species into the wrong trophic category. The classification as omnivory is corroborated by the wide range of their $\delta^{13} \mathrm{C}$ values, which could reflect the large spectrum of organic matter sources upon which they can rely.

The SIMPER analysis also revealed that it is mainly the higher concentration of 18:4(n-3) fatty acid that isolates Ampelisca richardsoni from the other amphipods. These levels attest to a major dietary input of material originating from phytoplankton, such as cryptophytes and/or haptophytes (Harrington et al. 1970, Nichols et al. 1991, Graeve 1993, Graeve et al. 1994a,b, 2001, Swadling et al. 2000). Fig. 4B clearly illustrates the drastic decrease of $\delta^{15} \mathrm{~N}$, the indicator of trophic position, along with an increase in the proportions of 18:4(n-3), a biomarker for the assimilation of fatty acids of phytoplankton origin (Harrington et al. 1970, Nichols et al. 1991, Graeve 1993, Graeve et al. 1994a,b, 2001, Swadling et al. 2000). In this case, confusion would have been caused by the use of stable isotopes alone to determine trophic links. If the $\delta^{15} \mathrm{~N}$ values indicate A. richardsoni and Djerboa furcipes as primary consumers, their respective fatty-acid profiles reveal that they do not rely on the same primary producers at all.

The rather isolated position of Iphimediella sp. (Fig. 2) seems to be due to the significant proportions of both isomers of the long-chain monounsaturated 20:1 and 22:1 fatty acids. These long-chain monounsaturates are typical components of dominant Antarctic copepod species Calanoides acutus and Calanus pro- pinquus (Hagen et al. 1993, 2000, Kattner et al. 1994). The significance of these copepod biomarkers in the fatty-acid pattern would put Iphimediella sp. in the zooplankton feeder group. However, its $\delta^{15} \mathrm{~N}$ value (the highest value in Fig. 4D), as well as its known predatory behaviour, strongly indicates that a trophic level exists between copepods and Iphimediella sp.

As illustrated in Fig. 3, where $\delta^{15} \mathrm{~N}$ is plotted against $\delta^{13} \mathrm{C}$, the other iphimediid species, Echiniphimedia hodgsoni, topped the trophic food web together with Iphimediella sp. With a diet essentially composed of sponges (Dauby et al. 2001b, F. Nyssen unpubl. results), the high trophic position of E. hodgsoni is unexpected. Stable-isotope ratios of Antarctic sponges can be quite high $\left(-22.3 \%\right.$ and $12.5 \%$ for $\delta^{13} \mathrm{C}$ and $\delta^{15} \mathrm{~N}$, respectively; Nyssen et al. 2002). This may be due to assimilation of rapidly sedimenting and isotopically heavy aggregates of sea ice origin (Dunton 2001) or to assimilation of resuspended matter that was cycled repeatedly through the microbial loop (Hobson et al. 1995, Nyssen et al. 2002 and references therein). The fatty-acid profile of $E$. hodgsoni did not show any sign of particular reliance on special food items. Its profile is dominated by 20:5(n-3) and 22:6(n-3), which are typical for marine organisms and predominant in membrane lipids (Sargent \& Whittle 1981, Sargent \& Henderson 1986, Albers et al. 1996, Graeve et al. 2001).

In conclusion, our study demonstrates that both fattyacid composition and stable-isotope ratios are suitable tools for trophic ecosystem analysis in their own right. Fatty acids point towards food-web links and stable isotopes identify trophic positions. However, the use of only 1 of the 2 tools can lead to misinterpretations with serious implications. A combination of the 2 approaches creates a 2-dimensional biomarker assay with higher accuracy and better trophic resolution.

Acknowledgements. We would like to thank Profs. A. Brandt (Hamburg) and W. Arntz (AWI, Bremerhaven) for their invitation to participate in the cruises ANDEEP and LAMPOS. We are also grateful to the officers and crew of the RV 'Polarstern', as well as to colleagues of the IRSNB (Brussels) and AWI (Bremerhaven), who helped in collecting and sorting samples. F.N. received a grant from the Belgian 'Fonds de la Recherche pour l'Industrie et l'Agriculture' (FRIA). The present research was performed under the auspices of the Scientific Research Programme on Antarctic (Phase V) from the Belgian Federal Office for Scientific, Technical and Cultural Affairs (Contract No. EV/36/24A).

\section{LITERATURE CITED}

Adams TS, Sterner RW (2000) The effect of dietary nitrogen content on trophic level ${ }^{15} \mathrm{~N}$ enrichment. Limnol Oceanogr 45:601-607

Albers CS, Kattner G, Hagen W (1996) The compositions of wax esters, triacylglycerols and phospholipids in Arctic 
and Antarctic copepods: evidence of energetic adaptations. Mar Chem 55:347-358

Auel H, Harjes M, da Rocha R, Stübing D, Hagen W (2002) Lipid biomarkers indicate different ecological niches and trophic relationships of the Arctic hyperiid amphipods Themisto abyssorum and T. libellula. Polar Biol 25:374-383

Bell MV, Sargent JR (1985) Fatty acid analyses of phosphoglycerides from tissues of the clam Chlamys islandica (Muller) and the starfish Ctenodiscus crispatus (Retzius) from Balsfjorden, northern Norway. J Exp Mar Biol Ecol 87:31-40

Burns JM, Trumble SJ, Castellini MA, Testa JW (1998) The diet of the Weddell seals in McMurdo Sound, Antarctica as determined from scat collections and stable isotope analysis. Polar Biol 19:272-282

Clarke KR, Warwick RM (1994) Change in marine communities: an approach to statistical analysis: an interpretation. Plymouth Marine Laboratory, Plymouth

Cook EJ, Bell MV, Black KD, Kelly MS (2000) Fatty acid compositions of gonadal material and diets of the sea urchin, Psammechinus miliaris: trophic and nutritional implications. J Exp Mar Biol Ecol 255:261-274

Dalsgaard J, St John M, Kattner G, Muller-Navarra D, Hagen W (2003) Fatty acid trophic markers in the pelagic marine environment. Adv Mar Biol 46:225-340

Dauby P, Scailteur Y, Chapelle G, De Broyer C (2001a) Impact of the main benthic amphipod species populations on the eastern Weddell Sea shelf ecosystem. Polar Biol 24:657-662

Dauby P, Scailteur Y, De Broyer C (2001b) Trophic diversity within eastern Weddell Sea amphipod community. Hydrobiologia 443:69-86

Dauby P, Nyssen F, De Broyer C (2003) Amphipods as food sources for higher trophic levels in the Southern Ocean: a synthesis. In: Huiskes AHL, Gieskes WWC, Rozema J, Schorno RML, van der Vies SM, Wolff WJ (eds) Antarctic biology in a global context. Backhuys Publ, Leiden, p 129-134

De Broyer C, Jazdzewski K (1996) Biodiversity of the Southern Ocean: towards a new synthesis for the Amphipoda (Crustacea). Boll Mus Civ Stor Nat Verona 20:547-568

De Broyer C, Rauschert M, Scailteur Y (1999) Structural and ecofunctional biodiversity of the benthic amphipod taxocoenoses In: Arntz W, Gutt J (eds) The expedition ANTARKTIS XV/3 (EASIZ II) of 'Polarstern' in 1998. Ber Polarforsch 301:163-174

De Broyer C, Scailteur Y, Chapelle G, Rauschert M (2001) Diversity of epibenthic habitats of gammaridean amphipods in the eastern Weddell Sea. Polar Biol 24:744-753

De Broyer C, Dauby P, Nyssen F, Martin P (2003a) Biodiversity, molecular phylogeny and trophodynamics of amphipod crustaceans in the Antarctic deep-sea. In: Fütterer DK, Brandt A, Poore GCB (eds) ANDEEP I and II: ANtarctic benthic DEEP-sea biodiversity — colonization history and recent community patterns. Ber Polarforsch 470:81-85

De Broyer C, Jazdzewski K, Dauby P (2003b) Biodiversity of the Southern Ocean: lessons from Crustacea. In: Huiskes AHL, Gieskes WWC, Rozema J, Schorno RML, van der Vies SM, Wolff WJ (eds) Antarctic biology in a global context. Backhuys Publ, Leiden, p 201-214

DeNiro MJ, Epstein S (1977) Mechanism of carbon isotope fractionation associated with lipid synthesis. Science 197: 261-263

DeNiro MJ, Epstein S (1978) Influence of the diet on the distribution of the carbon isotopes in animals. Geochim Cosmochim Acta 42:495-506

DeNiro MJ, Epstein S (1981) Influence of the diet on the distribution of the nitrogen isotopes in animals. Geochim Cosmochim Acta 45:341-351
Dunton KH (2001) $\delta^{15} \mathrm{~N}$ and $\delta^{13} \mathrm{C}$ measurements of Antarctic Peninsula fauna: trophic relationships and assimilation of benthic seaweeds. Am Zool 41:99-112

Falk-Petersen S, Hopkins CCE, Sargent JR (1990) Trophic relationships in the pelagic arctic food web. In: Barnes $M$, Gibson RN (eds) Trophic relationships in the marine environment. Proc 24th Eur Mar Biol Symp. Aberdeen University Press, Aberdeen, p 315-333

Fantle MS, Dittel AI, Schwalm SM, Epifiano CE, Fogel ML (1999) A food web analysis of the juvenile blue crab, Callinectes sapidus, using stable isotopes in whole animals and individual amino acids. Oecologia 120:416-426

Folch J, Lees N, Sloan-Stanley GH (1957) A simple method for the isolation and purification of total lipids. J Biol Chem 226:497-509

Fullarton JG, Dando PR, Sargent JR, Southward AJ, Southward EC (1995) Fatty acid of hydrothermal vent Ridgeia piscesae and inshore bivalves containing symbiotic bacteria. J Mar Biol Assoc UK 75:455-468

Gannes LZ, O'Brien DM, del Rio CM (1997) Stable isotopes in animal ecology: assumptions, caveats, and a call for more laboratory experiments. Ecology 78:1271-1276

Graeve M (1993) Umsatz und Verteilung von Lipiden in arktischen marinen Organismen unter besonderer Berücksichtigung unterer trophischer Stufen. Rep Polar Res 124: $1-141$

Graeve M, Kattner G, Hagen W (1994a) Diet-induced changes in the fatty acid composition of Arctic herbivorous copepods: experimental evidence of trophic markers. J Exp Mar Biol Ecol 182:97-110

Graeve M, Hagen W, Kattner G (1994b) Herbivorous or omnivorous? On the significance of lipid compositions as trophic markers in Antarctic copepods. Deep-Sea Res 41:915-924

Graeve M, Kattner G, Piepenburg D (1997) Lipids in Arctic benthos: Does fatty acid and alcohol composition reflect feeding and trophic interactions? Polar Biol 18:53-61

Graeve M, Dauby P, Scailteur Y (2001) Combined lipid, fatty acid and digestive tract content analyses: a penetrating approach to estimate feeding modes of Antarctic amphipods. Polar Biol 24:853-862

Graeve M, Kattner G, Wiencke C, Karsten U (2002) Fatty acid composition of Arctic and Antarctic macroalgae: indicators for phylogenetic and trophic relationships. Mar Ecol Prog Ser 231:67-74

Gutt J, Sirenko BI, Arntz W, Smirnov I, De Broyer C (2000) Biodiversity of the Weddell Sea: macrozoobenthic species (demersal fish included) sampled during the expedition ANT XIII/3 (EASIZ I) with RV 'Polarstern'. Ber Polarforsch 372:1-103

Hagen W (1988) On the significance of lipids in Antarctic zooplankton. Ber Polarforsch 49:1-117

Hagen W, Kattner G (1998) Lipid metabolism of the Antarctic euphausiid Thysanoessa macrura and its ecological implications. Limnol Oceanogr 43:1894-1901

Hagen W, Kattner G, Graeve M (1993) Calanoides acutus and Calanus propinquus, Antarctic copepods with different lipid storage modes via wax esters or triacylglycerols. Mar Ecol Prog Ser 97:135-142

Hagen W, Kattner G, Friedrich C (2000) The lipid compositions of five Antarctic fish species with different life strategies. Polar Biol 23:785-791

Harrington GW, Beach DH, Dunham JE, Holz GG (1970) The polyunsaturated fatty acids of dinoflagellates. J Protozool 17:213-219

Hobson KA, Welch HE (1992) Determination of trophic relationships within a high Arctic food web using $\delta^{13} \mathrm{C}$ and $\delta^{15} \mathrm{~N}$ analysis. Mar Ecol Prog Ser 84:9-18 
Hobson KA, Alisauskas RT, Clark RG (1993) Stable-nitrogen isotope enrichment in avian tissues due to fasting and nutritional stress: implications for isotopic analyses of diet. Condor 95:388-394

Hobson KA, Ambrose WG Jr, Renaud PE (1995) Sources of primary production, benthic-pelagic coupling, and trophic relationships within the Northeast Water Polynya: insights from $\delta^{13} \mathrm{C}$ and $\delta^{15} \mathrm{~N}$ analysis. Mar Ecol Prog Ser 128:1-10

Hobson KA, Schell D, Renouf D, Noseworthy E (1996) Stablecarbon and nitrogen isotopic fractionation between diet and tissues of captive seals: implications for dietary reconstructions involving marine mammals. Can J Fish Aquat Sci 53:528-533

Hobson KA, Sease JL, Merrick RL, Piatt JF (1997) Investigating trophic relationships of pinnipeds in Alaska and Washington using stable isotope ratios of nitrogen and carbon. Mar Mamm Sci 13:114-132

Howell KL, Pond DW, Billett DSM, Tyler PA (2003) Feeding ecology of deep-sea seastars (Echinodermata: Asteroidea): a fatty-acid biomarker approach. Mar Ecol Prog Ser 255: 193-206

Iverson SJ, Frost KJ, Lang SLC (2002) Fat content and fatty acid composition of forage fish and invertebrates in Prince William Sound, Alaska: factors contributing to among and within species variability. Mar Ecol Prog Ser 241:161-181

Jarre-Teichmann A, Brey T, Bathmann UV, Dahm C and 8 others (1997) Trophic flows in the benthic communities of the eastern Weddell Sea, Antarctica. In: Battaglia B, Valencia J, Walton DWH (eds) Antarctic communities: species, structure and survival. University Press, Cambridge, p 118-134

Jazdzewski K, Weslawski JM, De Broyer C (1996) A comparison of the amphipod faunal diversity in two polar fjords: Admiralty Bay, King George Island (Antarctic) and Hornsund, Spitsbergen (Arctic). Pol Arch Hydrobiol 42:367-384

Kattner G, Fricke HSG (1986) Simple gas-liquid chromatographic method for the simultaneous determination of fatty acids and alcohol in wax esters of marine organisms. J Chromatogr 361:263-268

Kattner G, Graeve M, Hagen W (1994) Ontogenetic and seasonal changes in lipid and fatty acid/alcohol compositions of the dominant Antarctic copepods Calanus propinquus, Calanoides acutus and Rhincalanus gigas. Mar Biol 118: 637-644

Kayama M, Araki S, Sato S (1989) Lipids of marine plants. In: Ackman RG (ed) Marine biogenic lipids, fats and oils, Vol 2. CRC Press, Boca Raton, FL, p 3-48

Kharlamenko VI, Kiyashko SI, Imbs AB, Vyshkvartzev (2001) Identification of food sources of invertebrates from the seagrass Zostera marina community using carbon and sulfur stable isotope ratio and fatty acid analyses. Mar Ecol Prog Ser 220:103-117

Klages M (1991) Biologische und populationsdynamische Untersuchungen an ausgewählten Gammariden (Crustacea: Amphipoda) des südöstlichen Weddellmeeres, Antarktis. PhD thesis, University of Bremen

Lee RF, Nevenzel JC, Paffenhöfer GA (1971) Importance of wax esters and other lipids in the marine food chain: phytoplankton and copepods. Mar Biol 9:99-108

Lepoint G, Nyssen F, Gobert S, Dauby P, Bouquegneau JM (2000) Relative impact of seagrass bed and its adjacent epilithic algal community in consumer diets. Mar Biol 136: 513-518

Michener RH, Schell DM (1994) Stable isotope ratios as tracers in marine aquatic foodwebs. In: Lajtha K, Michener RH (eds) Stable isotopes in ecology and environmental sciences. Blackwell Science, London, p 138-157
Minagawa M, Wada E (1984) Stepwise enrichment of ${ }^{15} \mathrm{~N}$ along food chains: further evidence and the relation between $\delta^{15} \mathrm{~N}$ and animal age. Geochim Cosmochim Acta 48:1135-1140

Nelson MM, Mooney BD, Nichols PD, Phleger CF (2001) Lipids of Antarctic Ocean amphipods: food chain interactions and the occurrence of novel biomarkers. Mar Chem 73:53-64

Nichols PD, Skerratt JH, Davidson A, Burton H, McMeekin TA (1991) Lipids of cultured Phaeocystis pouchetii: signatures for food-web, biogeochemical and environmental studies in Antarctica and the Southern Ocean. Phytochemistry 30:3209-3214

Nyssen F, Brey T, Lepoint G, Bouquegneau JM, De Broyer C, Dauby P (2002) A stable isotope approach to the eastern Weddell Sea trophic web: focus on benthic amphipods. Polar Biol 25:280-287

Peterson BJ, Fry B (1987) Stable isotopes in ecosystems studies. Annu Rev Ecol Syst 18:293-320

Phleger CF, Nichols PD, Virtue P (1998) Lipids and trophodynamics of Antarctic zooplankton. Comp Biochem Physiol 120B:311-323

Pinnegar JK, Polunin NVC (1999) Differential fractionation of $\delta^{13} \mathrm{C}$ and $\delta^{15} \mathrm{~N}$ among fishes tissues: implications for the study of trophic relationships. Funct Ecol 13:225-231

Rau GH, Hopkins TL, Torres JJ (1991a) ${ }^{15} \mathrm{~N} /{ }^{14} \mathrm{~N}$ and ${ }^{13} \mathrm{C} /{ }^{12} \mathrm{C}$ in Weddell Sea invertebrates: implications for feeding diversity. Mar Ecol Prog Ser 77:1-6

Rau GH, Sullivan CW, Gordon LJ (1991b) $\delta^{13} \mathrm{C}$ and $\delta^{15} \mathrm{~N}$ variations in Weddell Sea particulate organic matter. Mar Chem 35:355-369

Rau GH, Ainley DG, Bengston JL, Torres JJ, Hopkins TL (1992) ${ }^{15} \mathrm{~N} /{ }^{14} \mathrm{~N}$ and ${ }^{13} \mathrm{C} /{ }^{12} \mathrm{C}$ in Weddell Sea birds, seals and fish: implications for diet and trophic structure. Mar Ecol Prog Ser 84:1-8

Reinhardt SB, Van Vleet ES (1986) Lipid composition of twenty-two species of Antarctic midwater zooplankton and fishes. Mar Biol 91:149-159

Sargent JR (1976) The structure, metabolism and function of lipids in marine organisms. In: Malins DC, Sargent JR (eds) Biochemical and biophysical perspectives in marine biology. Academic Press, New York, p 149-212

Sargent JR, Henderson RJ (1986) Lipids. In: Corner EDS, O'Hara S (eds) Biological chemistry of marine copepods. Oxford University Press, Oxford, p 59-108

Sargent JR, Whittle KJ (1981) Lipids and hydrocarbons in the marine food web. In: Longhurst A (ed) Analysis of marine ecosystems. Academic Press, London, p 491-533

Scherrer B (1984) Biostatistiques. Gaëtan Morin, Québec

Schmidt K, Atkinson A, Stübing D, McClelland JW, Montoya JP, Voss M (2003) Trophic relationships among Southern Ocean copepods and krill: some uses and limitations of a stable isotope approach. Limnol Oceanogr 48:277-289

Swadling KM, Nichols PD, Gibson JAE, Ritz DA (2000) Role of lipid in the life cycles of ice-dependent and iceindependent populations of the copepod Paralabidocera antarctica. Mar Ecol Prog Ser 208:171182

Tieszen LL, Boutton TW, Tesdahl KG, Slade NH (1983) Fractionation and turnover of stable carbon isotopes in animal tissues: implications for ${ }^{13} \mathrm{C}$ analysis of diet. Oecologia 57: 32-37

Ulanowicz RE (2000) Growth and development: ecosystems phenomenology. Excel Press, San Jose

Wada E, Terazaki M, Kabaya Y, Nemoto T (1987) ${ }^{15} \mathrm{~N}$ and ${ }^{13} \mathrm{C}$ abundances in the Antarctic Ocean with emphasis on the biogeochemical structure of the food web. Deep-Sea Res 34:829-841

Submitted: November 1, 2004; Accepted: April 19, 2005

Proofs received from author(s): August 17, 2005 